\title{
Alison Lockyer: 'You think, it's 2019, why is this happening?'
}

By Kate Quinlan

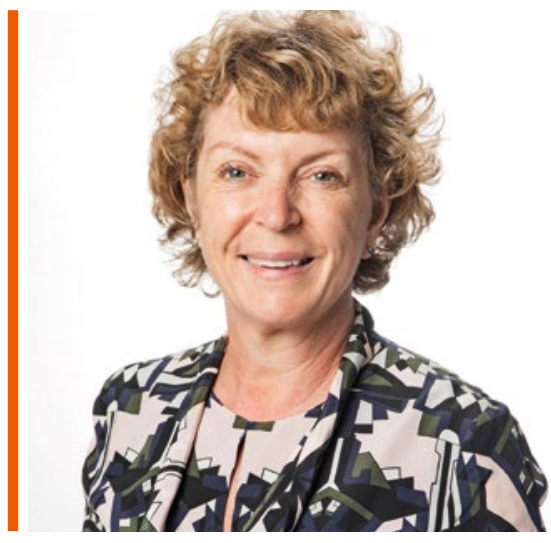

Besides working in general practice, how much of your time is taken up by being on the PEC and chairing the EEDTWG?

It averages a day a week, but sometimes it can be three days one week and then nothing the next. I travel to London for Board meetings but as Chair of the EEDTWG there are a lot of other things that I attend within my remit, again often in London, plus I always try and report back to my colleagues - there are 15 Non-Executive Directors of the PEC - and a daily email conversation amongst all of us. It's important that we all stay in the loop. It is quite a commitment, but one I love doing.

\section{What inspired your decision to help refugees?}

You see the news, and sometimes you just don't want to see such graphic reporting: the cameras (whether BBC or video clips recorded on phones) capture the horror. All these refugees are people like you and me but they're homeless, sometimes because their house has been bombed so they have no home, or just because they've had to move for their own physical or political safety. You think, it's 2019, why is this happening?

Two years ago, my husband and I decided to offer some accommodation - a converted coach house - to a refugee family, but we

Alison Lockyer has been a practising dentist for almost 40 years and runs a practice in Leicester. She is an elected member of the BDA's Principal Executive Committee (PEC) and within that, Chairs the Education, Ethics and the Dental Team Working Group (EEDTWG). This year, she helped move a family of Syrian refugees to live in an annexe of her home.

didn't know where to start. Friends and family had stayed at the coach house on and off but it was now unoccupied. I just thought that you'd put your hand in the air and say 'We have a three bedroomed house to offer' but it doesn't work like that. Despite what we see and read about other European countries taking in refugees, the UK has no easily visible process for us to simply hand over the place. going out there regularly with supplies... just an amazing bunch of people.

It grew out of that and the input from Tim and shared experience from other sponsorship groups who had already successfully brought in families and who explained what we needed to do. The first thing was to form a committee and have a charitable status, which we did via the

\section{'When the refugees arrive it is down to our group of 13 volunteers to organise everything, be it getting them bus passes, benefits, interpreters, English lessons, clothes...'}

\section{What did you do?}

By chance, there was an article in the Guardian that mentioned the work of Tim Finch and the UK Refugee Council, based in North London, so I called him.

The next thing I know, we had a meeting organised in February 2017 in Leicester and the word spread. We got the Salvation Army involved, people from the Refugee Council, the Cathedral, university academics, retired clergy, a teacher who is already helping refugees in Greece and
Salvation Army, and raise $£ 9,000$, because we are a private sponsorship group as opposed to a government one, and that is one of the conditions that has to be fulfilled before we could put in our application. In true Apprentice style we spent perhaps more time than we'd allocated on deciding a name for our group, our defence being that as we had to fundraise $£ 9 \mathrm{~K}$ we needed a description of who and what we were, the South Leicestershire Refugee Housing Committee, to have some credibility. 
The government are committed to bringing several thousand refugees in of their own accord; this is Government Sponsorship. The process is exactly the same for Private Sponsorship, but when the refugees arrive it is down to our group of 13 volunteers to organise everything, be it getting them bus passes, benefits, interpreters, English lessons, clothes - so the money we raise mainly covers the costs of that until they start receiving Universal Credit. We also need to organise schools for the kids, registration with doctors, dentist (that was the easiest bit!), job centre visits, bus timetables, halal food shops... so many things we take for granted are all so new and different to them, even something as banal as postcodes are a new concept for Syrians. When the refugees arrive at Birmingham Airport they travel with somebody from the Home Office to facilitate their passage through immigration, and they have a British Residency Permit enabling them to live here and work so some of the more technical stuff was thankfully taken off our hands by officials.

\section{How did you raise the $f 9,000$ ?}

It took a year. By running various events we publicised our case and received so much more: donations of children's clothes and toys; a local business gave us a hamper full of sample shoes, boots, slippers and woolly hats and scarves; a Lebanese couple cooked for a fundraising dinner for 30 and then refused to even take money for the ingredients; schools talked about Syrian children living in camps and collected money for us; and the local churches made us their charity when the Harvest Festival collection was given. Thankfully not one person to whom we spoke ever said anything at all negative (we'd been warned there may be some comments along the lines of 'charity begins at home') and the bonus was seeing just how many around us felt the same way about this humanitarian crisis and wanted to do something, to contribute.

\section{When did the refugee family move into your coach house?}

On 5 November, so it's very early days. It is two young parents and their children aged four and five. Both children are starting school next week. The local school has been fantastic; not only did they agree to take them straight away but they are also buying them school uniforms, school bags, PE kits and copies in Arabic of the books the kids will be reading first so that their parents can get involved.

I think this family were living in one room in Jordan for over six years, and the father was doing some off the books labouring work. That wouldn't be untypical judging by other stories I've heard, but refugees aren't actually allowed to work in Jordan and if he had been caught he would have been sent back to Syria and conscripted into the Army. They managed to survive financially and arrived in the UK with suitcases but have left large extended families behind so to leave that environment must make it extra difficult for them. I'm not sure, a week in, that that loss has yet been fully felt.

\section{How is the family's induction going so far?}

All of us in the community sponsorship group have been allocated roles and the Syrian family will be inducted into UK life via opening bank accounts, registering with the local council, visiting the schools, doctors, dentists, opticians, orientation, mosque visits, English lessons, budgeting, benefits, bus routes, food shopping and perhaps the biggest challenge, cooking on an Aga.

I usually see the family every day as my back door looks over their front door but we have a schedule of volunteer visits for the first month. The father of the refugee family is very keen to find work as he has always worked, whether as a pastry chef before the bakery was bombed, or in Jordan, so now that he's in the UK he's feeling

\section{'My first job as "landlord" was to show them the fire exits and alarms. The father of the family took it all in, though his escape from Syria and hand- to-mouth living in Jordan must have been far riskier.'}

The family were met with two translators, three 'meet and greet' from our group and a meal on the table prepared by another local Syrian family. My first job as 'landlord' was to show them the fire exits and alarms. The father of the family took it all in, though his experience of escape from Syria and handto-mouth living in Jordan must have been far riskier. When the mother saw me running the kitchen tap, she asked me what days we have water as normally as asking what days to put out the bins. That was quite a moment, realising just how hard wartime life is on a day in, day out basis.

\section{How are refugee families chosen to come to the UK?}

That's very interesting. We were told when we first started that it would be vulnerable people, so it was good that the accommodation offered had a downstairs bed and bathroom, but in reality the process is such that only fit, able, healthy, young families come over to the UK. They all go through a lot of medical tests and they're young, the kind of people governments would like as immigrants as they are going to be able, eventually, to contribute to the economy. a bit of a fish out of water with nothing to do. We've had an offer from a local restaurant that would like to help so something might come up fairly quickly. The family's English is far better than I expected, however, and the older child already knows her alphabet in English, but being in work is the quickest way to start speaking, in my experience, plus of course the kids will pick up a lot just by playing at school and being surrounded by chatter.

When the family were being shown round the local school, the parents asked plenty of questions of the school staff. I think their main concerns are around halal food and whether the children's new friends will offer them titbits of non-halal food. The head teacher allayed their fears - lunchtime is very closely supervised. The children seemed to relate well to their teachers, especially the five-year-old, who attempted (unsuccessfully) to negotiate the swap of a handbag for a lipstick that had caught her eye in her teacher's bag!

\section{What is your weekly time commitment to supporting the refugees?}

Well I'm the landlord or back-up if anything goes wrong, so I did all day yesterday and we took the family shopping for cold weather 
clothes. Although the house is fully equipped with sheets and towels I think it's a good sign that the mother wanted to buy her own - I think that's called 'nesting'. We spent an hour and a half in Asda; I admit I'm a champion shopper, but supervising two trolleys and two kids was testing.

One of the things we did the very first week was get the refugees registered at the job centre and from our fundraising money we give the family a weekly amount to buy food, until their benefits come through. There is a lovely couple in our group who are going to help the refugees with budgeting because the idea is that eventually we move the family into independence over the two years that we are committed to helping them. We want to get them into employment, into schools, settled, maybe in council housing, and then we can perhaps help another family.

We've offered the family three years in the coach house but it will be nice for them if they can get their own place before that. When I first spoke to Tim Finch, he said 'well you've got the difficult bit done, you've got a house. One of the problems with housing refugees is that if you go to a landlord and say we'd like to rent this house for a refugee family and they say 'okay when are they coming?' and you don't have a date, the landlord can't sit there with the house empty. So there's a bit of a catch 22 .

The mother had toothache so I have already taken a look at her teeth! The translator helped to explain what was going on during the appointment - it was helpful that the translator is a nurse.

\section{Is it challenging balancing your work for the refugees with your work commitments?}

The challenging thing is standing back and letting them find their own way, it's not up to us to micromanage their lives, but to be there for them and that will be a bit more hands-on in the first few weeks. I don't think it's really hit them yet that they've really left their extended family and how much that will impact on them.

The time commitment is probably one day a week, but Syrians are incredibly hospitable. If you knock on the door you have to go in for a coffee as a minimum; food is always offered, they are a very, very lovely family.

\section{Would you like $B D J$ readers interested} in helping refugees to contact you?

If anything in my experience touches a $B D J$ reader and they think perhaps that we have a moral duty to help, then they are welcome to contact me via dr.arlockyer@gmail.com.

I know there are a thousand more families out there, and maybe you'll think what difference does this make to the overall devastation of lives? But as I was talking to my practice manager about this, she reminded me of this story:

A girl on a beach covered with stranded starfish, is putting them back into the ocean. A man walks by and says to her:

'That's not going to make any difference is it, there are so many here.'

She listens to his words but then picks up another starfish and places it back in the sea, saying:

'Well, it's made a big difference to that one!'

We're fresh out of empty coach houses, but if you have one, please let me know. 